\title{
ANALYSIS OF SOIL TILLAGE BY PLOUGHS AND OPTIMISATION OF THEIR AGGREGATION
}

\author{
Iryna Novakovska ${ }^{1}$, Volodymyr Bulgakov ${ }^{2}$, Adolfs Rucins ${ }^{3}$, Ilmars Dukulis ${ }^{3}$ \\ ${ }^{1}$ National Aviation University, Ukraine; ${ }^{2}$ National University of Life and Environmental Sciences of \\ Ukraine, Ukraine; ${ }^{3}$ Latvia University of Life Sciences and Technologies, Latvia \\ ilmars.dukulis@1lu.lv
}

\begin{abstract}
The mechanical and technological aspects of the impact of ploughing upon the soil fertility have been analysed, as well as the frequency of its crumbling and restoration of the strength of the structure in the arable horizon under the current conditions of agricultural farming. So, a decision on the need for ploughing with a mouldboard plough is not taken every year, but when the soil structure coefficient of the upper layer $(8-10 \mathrm{~cm})$ is less than 0.67. A rational of use of mouldboard ploughs with coulters (or application of double-depth ploughs) is substantiated. Scientifically-grounded recommendations for the aggregation of the ploughing machine-andtractor aggregates have been presented. Reduction in the energy costs of ploughing can be ensured by introducing a correct system of aggregating the ploughing tools with energy resources.
\end{abstract}

Keywords: soil tillage, structure, fertility, plough, colder.

\section{Introduction}

In scientific literature investigations of the recovery processes of the soil structure as one of the most important indicators of preservation of its fertility are sometimes contradictory. The issues concerning preservation of soil fertility have been dealt with great interest in the scientific literature. In addition, starting from the activities of I. E. Ovsinsky [1] and ending with the present time, scientists and outstanding producers [2-4], directly linking preservation of soil fertility depending on the soil tillage system, systematically claim the technical and economic inexpediency and even agrotechnical harm of soil ploughing. Therefore, scientifically grounded recommendations for ploughing from the viewpoint of the preservation and increasing of soil fertility still remain topical.

In many published scientific works a negative or sceptical attitude to the basic soil tillage by the mouldboard plough has been expressed to a greater or lesser extent recently, i.e. to ploughing [3]. Scientists and producers in many countries of the world systematically assert that the technical and economic expediency and agrotechnical benefits of the mouldboard soil tillage using ploughs are minimal. Such statements are often justified from the point of view of a continuous decline in the soil fertility, which is just owing to annual ploughing of the soil. At the same time it is directly pointed to the fact that this negative phenomenon is precisely due to deep tillage - ploughing, regardless of the type of the soil, its fractional composition, physical and mechanical characteristics, etc.

The well-known classic - the soil scientist V. R. Williams [5] emphasized that the yield of any crop depends on the presence of many vital factors, among which the leading place is occupied by moisture and nutrients. Not a single gram of water or organic compounds can penetrate the organism of any plant other than through its root system located in the soil layer. Hence, we arrive at a logical conclusion that the soil fertility is its ability to provide the vitality of plants at simultaneous presence of two factors of their existence - moisture and nutrients [5;6], i.e. by its structure the soil may be at least in two opposite states: lumpy (i.e. structured) and single-particle (i.e. non-structured).

The first of these states represents a more or less loose stratum consisting of a set of soil lumps with a diameter of 1 to $10 \mathrm{~mm}$. The first of these states represents a more or less loose stratum consisting of a plurality of soil lumps with a diameter of 1 to $10 \mathrm{~mm}$. And they are formed with the help of such special "cement" which is humus. In the second state there are also separate soil particles, between which there is no any interconnection, they lie already as an overall mass to the entire depth of the fertile horizon, which adversely affects the conditions for the development of the root system of plants.

The motivation to replace ploughing with other methods of soil tillage is mainly based on the desire to reduce energy costs (under the conditions of an increased fuel price for tractors) [3]. However, there exist and are not completely used also other reserves to reduce the specific fuel consumption, which could, in general, solve this problem without violating the classical technology. 


\section{Materials and methods}

The purpose of the present investigation is to analyse the issue, how to increase natural fertility of the soil in Ukraine by using a mouldboard, and to study a possibility to reduce the resistance of ploughs at the expense of an optimal choice of the aggregation parameters.

Extensive analysis of classical works and modern investigations of the structure of soils, and in particular the chernozem soils (black soil) of Ukraine, was carried out.

In order to determine the state of the soil according to the standard methodology [5], the soil density, its porosity in \% (i.e. the total amount of all the pores among the particles of the solid phase of the soil as a percentage from the total soil volume), the percentage of agronomically valuable fractions (entering the range of the soil particles from 10 to $0.25 \mathrm{~mm}$ ) and the strong, not water-washable fractions (for the evaluation of the water resistance), etc. were estimated.

To assess the marginal structure of the soil using the screening method through a sieve, the structure coefficient $K_{C}$ was determined, i.e. by the relative amount of agronomically valuable aggregates including the lumps of the soil with a diameter from 0.25 to $10.0 \mathrm{~mm}$ [5]:

$$
K_{C}=\frac{\sum M_{a}}{\sum M_{o}},
$$

where $M_{a}$ - mass of the soil particle with a diameter 0.25 to $10.0 \mathrm{~mm}$;

$M_{o}$ - mass of the soil particle with a diameter less than $0.25 \mathrm{~mm}$ and more than $10.0 \mathrm{~mm}$.

In order to reduce the resistance of the plough in work, it is proposed to justify such a scheme of aggregation, under which minimum pressure upon the landside of the plough bodies is ensured. To create a balance of forces, well-known theoretical assumptions of agricultural mechanics for the ploughs were applied [7].

\section{Results and discussion}

The chernozem soils (black soil) of Ukraine are rich in humus, accumulated by nature for centuries. Yet, their uncontrolled use during the last 25 years (without appropriate agrotechnical measures and in the pursuit of quick profits from the tillage of monocultures) leads to the fact that the weighted average indicator of the humus content in the arable lands of Ukraine is constantly decreasing; especially this fall was great in the late 90s of the 20th century (Fig. 1) [8].

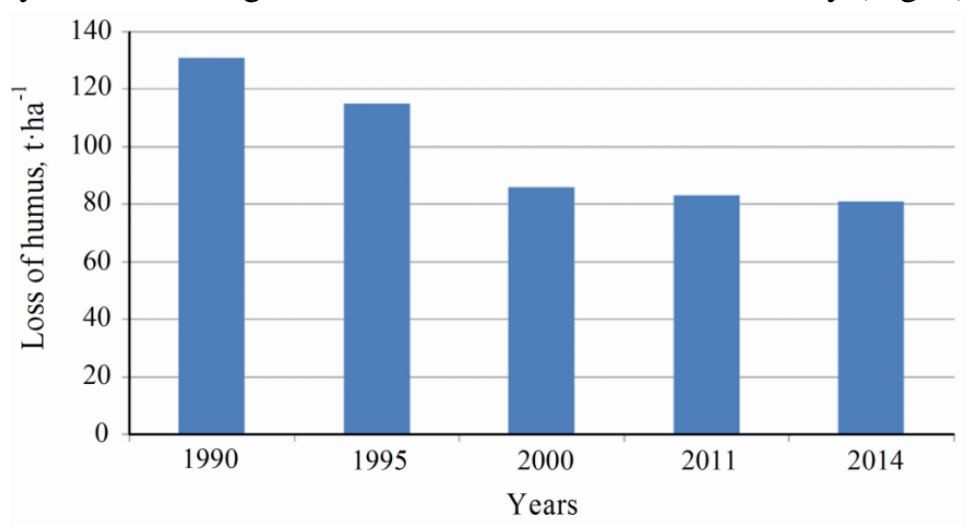

Fig. 1. Dynamics of humus content in soils of Ukraine

In most countries with developed arable farming, there is a problem of soil overpacking, first of all, by the undercarriage systems of the multiply used tractors and heavy agricultural implements. It is believed that almost 22 million hectares of arable land in Ukraine already suffer from excessive overpacking [3]. And although recommendations for overcoming this negative phenomenon have been developed in the world in large numbers, in practice their use is limited in most cases, which ultimately leads to the fact that the average density of soils is steadily increasing. As it is known, a great amount of humus in the soil decreases its lesser density. This is evidenced by the data of many sources and our calculations on the PC for the chernozems of Ukraine (Fig. 2) [8]. 


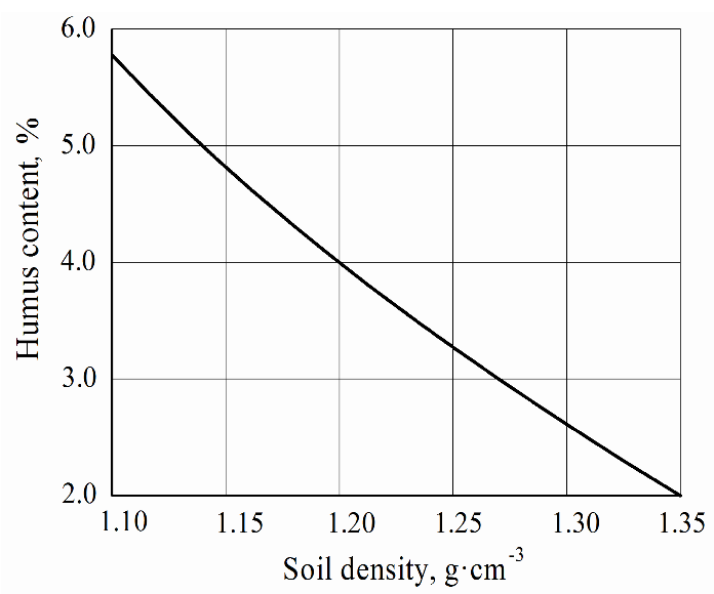

Fig. 2. Soil density depending on humus content in it for chernozems of Ukraine

In a non-structured particle state of the soil the space between its particles is filled either with air or moisture. In the first case, an intense aerobic process takes place in it; yet, in the absence of water the cultivated plants do not have the opportunity to use nutrient substances. In this case a more or less good yield is the result of frequent, but not heavy rains. On the contrary, if there is only moisture in the non-structured particle soil, decomposition of the organic residues is significantly slowed down or completely stopped. Since only the lumpy soil structure is capable to supply the cultural plants simultaneously with moisture and nutrients, it should be constantly maintained in this state (let us call it conditionally the first task of modern soil tillage). If the structure of the soil is destroyed by corresponding compaction (for example, by propulsors of the tractors), then, even if there is sufficient humus, the soil will lose its fertility. Simply in this case a significant part of the used humus will pass into the state of the non-used state. Over time, under the influence of precipitations and atmospheric air, its upper layer (approximately $8-10 \mathrm{~cm}$ in height) tends to gradual transition into a non-structured particle state [5]. This occurs because humus, as a product of the synthesis of anaerobic bacteria, easily disintegrates under aerobic conditions, and any interconnection among the particles of the soil is gradually lost. This phenomenon is facilitated, to a certain degree, by the replacement of the calcium cation $\left(\mathrm{Ca}^{2+}\right)$ with the ammonium cation $\left(\mathrm{NH}^{4+}\right)$ in humus, as well as by the mechanical tillage of the soil medium when, together with the restoration of its lumpy structure, there takes place partial loosening and pulverisation of the lumps. As the final result, the upper layer of the soil gradually loses its fertility. This process can only be slowed down, but it cannot be stopped completely. Hence follows the second task of soil tillage [5] - periodic restoration of the strength of the structure of the upper soil layer. Considering what was mentioned above, one can state that loosening of the soil can be carried out (and often it is even necessary) every year, but the strength of its structure must be restored only once every few years. It is possible to restore the lumpy structure of the soil by its nonmouldboard tillage. In this case the proponents of ploughing will not argue about the efficiency of such a decision aimed at minimisation of the wind erosion of the agricultural background, on the one hand; and the economic purposefulness in terms of the costs of the soil tillage on the other. True only until the moment when the upper layer of the soil is still structured. Otherwise, the unstructured soil particles will simply wake up and start undesirably diluting the lower horizon, gradually bringing it into a non-structured particle state. In this case even non-mouldboard tillage of the soil becomes not only undesirable but also harmful. The proponents of the "no-till" technology argue that deep loosening of the soil by mechanical means is not necessary at all. But in our opinion this is not true and here it is essential to consider a more important issue how to restore the strength of the structure of the upper soil layer. For this purpose the upper layer should be mechanically removed and replaced by a new horizon with the necessary production properties [5], i.e. this layer of soil should be brought to such conditions, under which it could restore the strength of the structure and the ability to crumble; and isolated from the influence of the dropping liquid atmospheric water, in which ammonium salts are necessarily present. Besides, because of the extremely weak concentration of the solutions of these salts [5], they are in a state of complete ionization. Therefore the ammonium cation penetrates into the surface layer of the soil and displaces there the calcium cation, which is an integral part of the active humus (humus). As a result, the soil loses its strength and structure. 
The above-mentioned task of changing the two layers of soil in places can be solved so far only by working elements - ploughs, the design of which ensures the movement of the upper layer to a certain depth. Under the conditions of Ukraine, when the so-called. "cultural" (cylindrical) bodies of the ploughs are used, they must be ploughs necessarily equipped with coulters (or double-deck ploughs). Under other conditions these may be plough bodies equipped with trashboard [2; 7].

As it is known, the plough body with the coulter performs turning of the soil layer in two steps. At first, the coulter removes the upper part of the soil layer and drops it to the bottom of the furrow, actually breaking down the unstructured soil over the least resistant surfaces of the clod, and then the main body of the plough lifts them from below and pours them over with the lumpy (structured) mass. Further, the restoration process of the strength of the structure starts in the lower layer formed under anaerobic conditions exactly in this way. But after what period of time should ploughing be repeated as a way to restore the strength of the soil structure? The range of opinions on this issue is wide - some scientists say that it should be carried out in 2-4 years, others think that after 4-5 [8], etc. Another thing is that the basis for their justification about the need for this important technological operation is not the task to restore the soil structure, but other factors. Namely, if you do not periodically turn over the layer of the soil, then in its upper layer there will accumulate organic substances, besides, with an increasingly infectious potential. Or, with prolonged surface tillage and high intensity of the phosphorus and potassium balance, their accumulation may exceed the optimal load on the root system of the plants.

On the basis of the foregoing, one can state that, since the loss of structurality of the upper layer by the soil and its restoration by the lower layer does not occur in one year, there is virtually no need for annual ploughing. And therefore the horizon of the arable soil can be "exploited" until its upper layer depth of $8-10 \mathrm{~cm}$ reaches the marginal structure. Analysis of a number of data [6] and our investigations indicate that under the conditions of chernozem soils (black soil) in Ukraine a decision on the need for ploughing by a mouldboard plough should be taken, when the values of the soil structure coefficient are lower than 0.67 . However, in a general case, this issue is obviously not so simple, and the definition of periodical ploughing under other soil and climatic conditions and the order of the crop rotation requires in each particular case special studies.

Ploughing recently is often carried out without coulters. Because of this, simple mixing of the upper (unstructured) and the lower (not still sufficiently structured) layers of the soil occurs with a gradual loss of its structure throughout the entire ploughing horizon. Therefore, the latter layer turns into a homogeneous medium whereas, when ploughing with a coulter, the arable horizon is heterogeneous. The idea that the coulter increases the resistance of the plough is also incorrect $[9 ; 11]$. In addition, to solve the problem of reducing the energy costs of ploughs [2; 7], many recommendations have been developed, which certainly deserve much attention. For example, under the conditions of the Baltic countries, installation of high-speed screw-type bodies for stony soils increased to the $50 \mathrm{~cm}$ working width and a corresponding increase in the total working width of the 3- to 7-furrow ploughs for better loading of the new more powerful tractors is technically and agronomically feasible and purposeful. This reduces the specific draught resistance of the ploughs by $14-26 \%$, improves the efficiency of the ploughing aggregates by $25-42 \%$, lowers the specific fuel consumption by $14-26 \%\left(3-4 \mathrm{~kg} \cdot \mathrm{ha}^{-1}\right)$ and minimises correspondingly the cost of the ploughing operations.

The field studies, conducted in Latvia, showed that, after deep ploughing $(20-25 \mathrm{~cm})$, the next two years the soil can be ploughed finer $(15-18 \mathrm{~cm})$ without affecting the yield. Reduction in the ploughing depth by $1 \mathrm{~cm}$ reduces the fuel consumption by $0.4-0.6 \mathrm{~kg} \cdot \mathrm{ha}^{-1}$ and the costs.

The basic parameters of the plough body values, which determine the draught resistance of the plough-bottom surface and the body, as a whole, are: the cutting angle $\varepsilon_{1}$ (setting of the ploughshare to the bottom of the furrow), curvature of the lifting surface, characterised by its radius $r$, the final turning angle of the layer $\varepsilon_{2}$ and the inclination angle of the generatrix to the direction of the movement $\gamma_{p}$, and $\varphi$ - the angle of friction of the soil against the wall of the landside. Parameters $\varepsilon_{1}, r$ and $\varepsilon_{2}$ are determined, to a great extent, by the technological process of ploughing, and they vary within narrow limits. Yet, $\gamma_{p}$ may vary over large limits and therefore it has a more significant impact upon the resistance of the plough-bottom surface. On loamy soils the optimum value of the inclination angle of the horizontal generatrix of the plough-bottom surface to the furrow wall decreases from $46^{\circ}$ to $30^{\circ}$, the speed decreasing from 1.5 to $3 \mathrm{~m} \cdot \mathrm{s}^{-1}$. Application of ploughs with optimal parameters 
(inclination) of the horizontal generatrix of the plough-bottom surface of the bodies for ploughing the soil at high speeds $\left(3-4 \mathrm{~m} \cdot \mathrm{s}^{-1}\right)$ of the bodies makes it possible to reduce their draught resistance by $12-20 \%$.

In our work we will note in more detail one of the ways to reduce the resistance of the plough which, in our opinion, is little reflected in the scientific literature. Thus, the energy costs in ploughing can be significantly reduced, if a correct method of aggregating (joining) the plough with the power tool is carried out. It was believed until recently that the smallest traction resistance of the plough can be reached by its symmetrical attachment to the tractor. For this, the following conditions must be fulfilled:

$$
B_{a c}=b_{k} \cdot(n+1)-2 A-b,
$$

and

$$
B_{a c}^{\prime}=b_{k} \cdot(n+1)+b,
$$

where $B_{a c}, B_{a c}^{\prime}$ - track of the power tool (tractor), when the propulsors of its right-side board are moving beyond the furrow and in the furrow, respectively (movement of caterpillar tractors with the plough takes place only outside the furrow);

$b_{k}$ - constructive working width of the plough body;

$n$ - number of bodies of the ploughing implement;

$A$ - distance from the furrow to the outer edge of the propulsors;

$b$ - propulsor width of the tractor.

In case the actual value of the track $B_{a c}$ of the power tool is greater than the required value, the plough is connected not symmetrically, but with a right-side lateral displacement $e_{b}$, the value of which is determined as follows:

$$
e_{b}=\frac{B_{a c}-B_{r e}}{2} .
$$

In the case of a three-point adjustment of the rear hitch mechanism of the aggregating tractor this displacement can only be achieved by displacing the ploughing implement relative to its own coupling device. This leads to formation of the angle $\gamma$ between the longitudinal axis of symmetry of the tractor and the line of the towbar. The latter, in turn, provides not only an increase in the turning moment, but also leads to the appearance of a lateral (transverse) component of the tractive effort, which causes an additional force of friction of the plough landside against the furrow wall. As a result, the draught resistance of the ploughing implement increases. Thus, according to [9; 11], at the right-side transverse displacement of the plough with respect to its own coupling device only by $100 \mathrm{~mm}$, its draught resistance increased by $9 \%$, while the fuel costs were increased by $5 \%$ at the same time.

In the two-point scheme, the right-side transverse displacement of the ploughing implement can be carried out as described above and also by corresponding displacement of the lower towbars of the rear coupling of the aggregating tractor by a predetermined value. Since in this case the value of the angle $\gamma$ (if there is any) does not change, then the draught resistance of the plough remains practically constant and the unfolding moment created by it has a tendency to decrease.

It follows from above, if, according to conditions (2) or (3), the parameters of the tractor undercarriage system do not allow to attach the plough symmetrically, it is better to use a two-point hitch scheme of the rear coupling mechanism of the power tool. Besides, the right-side transverse displacement of the ploughing implement should, first of all, be made by moving the lower towbar of the hitch mechanism of the aggregating tractor. And only when this displacement is not sufficient, it is necessary to move the frame of the ploughing implement relative to its own connecting rods (bolsters).

If the parameters of the tractor undercarriage system allow symmetrical aggregation of the plough, the power tool can have only one scheme for the adjustment of the rear three-point hitch mechanism. Moreover, unlike the two-point hitch mechanism, it does not need adjustment, when the tractor is working with other hitched up machines or implements. The high traction and coupling properties and a relatively narrow track of the power tool can ensure attachment of the plough to it not only symmetrically, but also with a left-side transverse displacement relative to its own connecting 
rods, determined from expression (4). By the way, such a variant of aggregation of the ploughing implement is implemented with the use of modular energy facilities. In this case the lateral component of the tractive force of the modular power tool has an impact on the reduction of the load upon the landside of the plough. Thus, for example, according to the results of numerous experimental field studies, processed by us on the PC, when the modular energy equipment was aggregated with a standard six-bottom plough, its left-side lateral displacement ensured only for $100 \mathrm{~mm}$ reduction in the draught resistance of the ploughing implement by $9-14 \%$, and the hourly fuel consumption - by $9.8 \%$ $[7 ; 11]$. It is quite natural that at a certain value of such a movement of the plough, complete unloading of its landside can take place with inevitable stability violation of the movement in a horizontal plane. To avoid this phenomenon, the maximum value of the left-side transverse displacement of the ploughing implement relative to its own hitch device must satisfy the following condition:

$$
e_{t r \max }<D \cdot \operatorname{ctg}\left(\varphi+\gamma_{o}\right),
$$

where $D$ - instance from the "resistance centre" of the plough to the "turning centre" of the rearmounted mechanism of the tractor;

$\varphi$ - friction angle of the soil against the wall of the landside;

$\gamma_{o}$ - angle formed by the blade of the share with the furrow wall.

The values obtained from expressions (3) and (4) are compared, and the least value is selected for practical use. In this case the correlation between the parameters of the undercarriage system of the aggregating power tool and the working width of the plough, as well as its condition of the stable operation will be taken into account. Taking into account (2), expression (4) can be presented in a more expanded form:

$$
e_{t r}=\frac{\left[B_{a c}+2 A+b-b_{k} \cdot(n+1)\right]}{2} .
$$

It follows from its analysis that the value of the transverse displacement of the "resistance centre" of the plough depends on the movement stability of the power tool. In expression (6) this is represented by the distance from the outer edge of the tractor propulsors to the furrow wall $(A)$. The less sensitive is the power tool to disturbances, the lower is the value $A$, and vice versa.

Depending on the physical and mechanical properties of the soil and the movement stability of one or another power source within the ploughing machine-and-tractor aggregate, the distance $A$ can vary in the range of $10-29 \mathrm{~cm}[2 ; 11]$. At a larger value, as practice shows, it becomes more difficult for the operator to trace the furrow edge of the previous pass of the aggregate, which increases irregularity of its working width. At a lower value $A$, a hazard arises that the right-side propulsors of the aggregating power tool may slide into the furrow.

These assumptions are considered as an example with the most common Ukrainian ploughs and tractors. For a tractor of the traction class 3, when working with 5-bottom ploughs, the indicated distance $A$ is selected in practice sufficiently close to the value of the ploughing depth of ploughing. On average, this makes $27 \mathrm{~cm}$, which is close to what is recommended in [10;12]. Since for the agricultural aggregates, most widespread in Ukraine, the working width of the plough body $b_{k}=35 \mathrm{~cm}$, and the width of the tractor tire $b=54 \mathrm{~cm}$, then, as follows from expression (1), the necessary value of the track of the power tool should be equal to: in the aggregate with a standard fivebottom plough $(n=5)-102 \mathrm{~cm}$; in the aggregate with a standard six-bottom plough $(n=6)-137 \mathrm{~cm}$. As the wheeled tractor of the traction class 3 has a track $B_{a c}=168 \mathrm{~cm}$, then in both cases a right-side transverse displacement of the "resistance centre" of the ploughing implement is needed. And this means that, in case the ploughs are aggregated with the tractor, the rear-mounted hitch mechanism of the tractor of the traction class 3 should be adjusted according to a two-point scheme. Unlike the wheeled tractor, the caterpillar tractor of the traction class 3 is more stable to the impact of the same unfolding moment upon it. As practice shows, in an aggregate with the ploughs mentioned, it can move without sliding into the furrow at a distance from its wall to the edge of the caterpillar band 10 to $12 \mathrm{~cm}$. If we take into consideration that for this power tool $b=43 \mathrm{~cm}$, then at $A=10 \mathrm{~cm}$ we obtain: $B_{r e}=147 \mathrm{~cm}$ - when working with a standard five-bottom plough, and $B_{r e}=182 \mathrm{~cm}-$ when working with a standard six-bottom plough. Since the tractor of the traction class 3 has $B_{a c}=147 \mathrm{~cm}$, then in 
the first case we have a symmetrical attachment of the ploughing implement but in the second case we have an aggregate with a left-side transverse displacement of its " resistance centre" by a value of $17.5 \mathrm{~cm}$. Hence, it follows that a caterpillar tractor of the traction class 3 can only have a three-point rear-mounted hitch mechanism.

\section{Conclusions}

1. To restore the strength of the soil structure periodically, it is necessary to carry out systematically its basic soil tillage by ploughs, with obligatory use of coulters (devices of similar purposes for two-bottom ploughs, etc.). Total refusal from ploughing is not justified. In order to determine the frequency of ploughing, taking into account the soil and climatic conditions and the order of the crop rotation, in each case special studies are required.

2. One way to reduce the energy costs of ploughing is to introduce a correct system of aggregation of the ploughing implements with tractors. When modular tractor equipment is aggregated with a standard six-bottom plough, the left-side transverse displacement of the latter only by $100 \mathrm{~mm}$ reduced the draught resistance of the ploughing implement by $9-14 \%$, and the hourly fuel consumption by $9.8 \%$.

3. On loamy soils, the optimum value of the inclination angle of the horizontal generatrix of the plough-bottom surface to the furrow wall decreases from $46^{\circ}$ to $30^{\circ}$, the speed increasing from 1.5 to $3 \mathrm{~m} \cdot \mathrm{s}^{-1}$. The use of ploughs with optimal parameters (the slope of the horizontal generatrix) of the plough-bottom surface of the bodies for ploughing soil at high speeds $\left(3-4 \mathrm{~m} \cdot \mathrm{s}^{-1}\right)$ makes it possible to reduce their draught resistance by $12-20 \%$.

\section{References}

[1] Овсинский И. Новая система земледелия (A new system of farming). Moscow, 1909. 108 p. (In Russian).

[2] Vilde A., Rucins A. Simulation of the Impact of the Plough Body Parameters, Soil Properties and Working Modes on the Ploughing Resistance. $10^{\text {th }}$ International Conference on Computer Modelling and Simulation. Emmanuel College Cambridge, 1 - 3 April 2008, pp. 697 - 702.

[3] Шикула Н. Почвозащитная система земледелия (A soil protection system of agriculture). Harkiv, 1987. 200 p. (In Ukrainian).

[4] Blanco-Canqui H. Soil structure and organic carbon relationships following 10 years of wheat straw management in no-till. Journal Soil and Tillage Research, Vol. 95 (1), 2007, pp 240-254.

[5] Вильямс В. Почвоведение. Земледелие с основами почвоведения (Soil science. Agriculture with the fundamentals of soil science). Moscow, 1951. 576 p. (In Russian).

[6] Шеин Е. Агрофизика (Agrophysics). Rostov-an-Don, 2006. 400 p. (In Russian).

[7] Vilde A., Rucins A. Impact of Friction on the Plough Body Draft Resistance. Tarim Makinalari Bilimi Dergisi, Journal of Machinery Science. Published by Agricultural Machinery Association, Antalya-Turkiye, 2008, pp. 179 - 185.

[8] Аулин В. Состояние самоорганизации среды почвы и закономерности износа рабочих органов почвообрабатывающих машин. (The state of self-organization of the soil environment and patterns of wear of the working tools of tillers). Problems of Tribolodgy, No 1, 2013. pp. 114118. (In Ukrainian).

[9] Пупонин А. Научные и практические основы совершенствования обработки почвы в интенсивном земледелии центрального района нечерноземной зоны. (Scientific and practical basis for improving soil tillage in intensive farming in the central region of the non-chernozem zone). Ckishinev, 1986. 50 p. (In Russian).

[10] Шикула Н. Минимальная обработка черноземов и воспроизводство их плодородия (Minimal processing of chernozems and reproduction of their fertility). Moscow, 1990. 320 p. (In Russian).

[11] Булгаков В. Кравчук В., Надыкто В. Агрегатирование плугов (Aggregation of ploughs). Kyiv, 2008. 152 p. (In Ukrainian).

[12] Shevchenko N. The influence of soil tillage systems on agro-physical properties of typical black soil and crop rotation productivity in Ukraine forest-steppe. Bulletin of the Belarussian State Agricultural Academy, No 4, 2014, pp. 49-53. 